\title{
PENGEMBANGAN INSTRUMEN E-TEST SEBAGAI INOVASI PENILAIAN BERBASIS ONLINE DI SEKOLAH DASAR
}

\author{
Kuncahyono, Maharani Kumalasani, Dian Aini \\ FKIP Universitas Muahmmadiyah Malang, Indonesia \\ Email: kuncahyono@umm.ac.id
}

\begin{abstract}
ABSTRAK
Sekolah Dasar Negeri Tlogomas 2 Malang merupakan sekolah yang sudah menerapkan kurikulum 2013. Para guru sudah menerapkan pembelajaran tematik terpadu, dan mencoba mengaplikasikan media dalam kegiatan pembelajaran di kelas. Namun dalam melaksanakan penilaian hanya menggunakan perangkat instrumen paper based test. Penelitian ini bertujuan untuk menghasilkan produk instrumen e-tes berbasis online. Instrumen digunakan sebagai sarana untuk mempermudah guru dalam melakukan penilaian secara sistematis dan praktis. Penelitian ini menggunakan model pengembangan O' Malley dan Pierce yang disesuaikan dengan kebutuhan penelitian melalui lima tahapan yaitu: 1) menentukan tujuan pengembangan, 2) menyusun spesifikasi produk, 3) melakukan pengembangan, 4) uji coba, dan 5) revisi. Teknik pengumpulan data menggunakan angket validasi ahli dan pengguna (guru dan siswa). Hasil penelitian menghasilkan produk instrumen e-test berbasis online yang valid setelah divalidasi oleh validator, hasil uji coba ahli mendapat kriteria valid. Hasil Uji coba pengguna mendapat kriteria praktis. Validitas e-test yang dikembangkan termasuk dalam kategori sangat layak yang berarti memiliki validitas yang tinggi. Hasil uji coba skala luas yang dilakukan kepada seluruh siswa di kelas IV SDN Tlogomas 2 Kota Malang mendapatkan hasil 89,3\% sangat menarik untuk digunakan sebagai alat evaluasi dalam pembelajaran. Selain itu siswa terlihat sangat antusias dalam mengerjakan e-test dan fokus pada e-testnya masing-masing, sehingga mampu meminimalisir kecurangan dalam pelaksanaan pengerjaan soal dan penilaian.
\end{abstract}

Kata Kunci : Instrumen e-test; Online; Penilaian online

\section{ABSTRACT}

Tlogomas 2 Malang Elementary School has implemented the 2013 curriculum. The teachers have implemented integrated thematic learning, and are trying to apply the media in classroom learning activities. But in carrying out the assessment, the teachers only uses a paper-based test instrument. This research aims to produce online-based, e-test instrument products, used as a means to facilitate teachers in conducting systematic and practical assessments. This research uses the $\mathrm{O}$ 'Malley and Pierce development model based on an analysis of research needs through five stages as follows: 1) determining the development objectives, 2) developing product specifications, 3) developing, 4) testing and 5) revising. The data collection techniques employed expert and user validation questionnaires (teachers and students). The results of the research showed a valid online-based e-test instrument product after being validated by a validator. The validity test of expert trials received valid criteria. The validity test of trial from users also received valid practical criteria. The validity of the e-test that was developed is included in the very feasible category, which means it has high validity. The results of a wide-scale trial conducted on all students in class IV SDN Tlogomas 2 Malang scored $89.3 \%$, which is very interesting to be used as an evaluation tool in learning. In addition, students look very enthusiastic in working on e-tests and focus on their own e-tests, so as to minimize cheating in the implementation of the assignments and assessments.

Keywords: E-test Instrument; Online Evaluating; Online 


\section{PENDAHULUAN}

Masyarakat berkualitas merupakan masyarakat yang cerdas. Untuk menjadi cerdas diperlukan proses pendidikan yang bermutu dan kunci utama dalam peningkatan mutu pendidikan adalah mutu guru. Proses pendidikan dalam masyarakat abad 21 adalah suatu interaksi antara guru dengan peserta didik sesuai dengan kemajuan ilmu pengetahuan dan teknologi dalam masyarakat yang demokratis dan terbuka (Depdiknas, 2008). Selain itu, sebagai seorang guru, seharusnya memiliki kompetensi yang memadai untuk melakukan tugas membimbing, membina, dan mengarahkan peserta didik dalam menumbuhkan semangat keunggulan, motivasi belajar, dan memiliki kepribadian serta budi pekerti luhur yang sesuai dengan budaya bangsa Indonesia (Mulyana, 2007). Melihat penjelasan tugas sebagai seorang guru, maka kita semua mengetahui bahwa begitu banyak tantangan yang dihadapi oleh seorang guru dalam upaya untuk melaksanakan tugasnya di masa yang akan datang, yaitu guru yang siap dalam mendidik siswanya menghadapi masyarakat abad 21.

Barnett (2012) mengungkapkan bahwa jenis pertanyaan tingkat tinggi mampu menciptakan siswa untuk berpikir lebih mendalam terkait materi pelajaran. Hal ini dapat dikatakan bahwa melalui tes kemampuan berpikir tingkat tinggi siswa mejadi leibh mudah terangsang untuk mengembangkan kemampuan berpikirnya. Lazimnya pertanyaan berpikir tingkat tinggi disebut HOT atau Higher Order Thinking yang meliputi kemapuan kemampuan menganalisis (analyze), mengevaluasi (evaluate), dan menciptakan (create) (Anderson \& Krathwohl, 2001:30). Berdasarkan penjelasan tersebut perlu dilakukan pelaksanaan penilaian yang tidak hanya mengukur kompetensi kognitif, tetapi juga mampu mengukur aspek psikomotor dan afektif.

Pada Abad 21 ini menjadi tantangan khusus bagi guru dalam melaksanakan tugasnya terutama dalam hal pembelajaran berbasis teknologi. Tantangan tersebut diharapkan guru selalu mengikuti perkembangan zaman, baik dari segi ilmu pengetahuan maupun dari segi teknologi. Penjelasan kondisi tersebut menyatakan bahwa guru sebagai masyarakat sekolah harus melek teknologi. Hal ini merupakan salah satu karakteristik dari gambaran abad 21. Pada Abad 21 ini ditandai hadirnya berbagai jenis instrumen dan fasilitas internet di 
dunia pendidikan yang memberikan banyak kemudahan dan pilihan dalam rangka menunjang proses pembelajaran. Teknologi memainkan peran penting dalam memperbarui pembelajaran yang bersifat konvensional menjadi pembelajaran berbasis teknologi. Perkembangan teknologi berpotensi dalam mengubah seseorang dalam belajar, baik untuk memperoleh informasi dan menyajikan informasi secara baik dan kompleks. Teknologi dapat dimanfaatkan oleh guru dalam mengembangkan kompetensinya dalam hal melakukan penilaian. Hasil dari FGD (Focus Group Discution) yang dilakukan tim peneliti di SD Tlogomas 2 Malang pada awal Juni 2018 didapatkan informasi, SD Tlogomas 2 Malang sudah menerapkan kurikulum 2013, guru-guru sudah menerapkan pembelajaran tematik terpadu, dan guru-guru juga sudah mencoba mengaplikasikan media dalam kegiatan pembelajaran di kelas. Namun dalam melaksanakan penilaian hanya menggunakan perangkat instrumen paper based test. Guru belum menggunakan penilaian secara online. Penelitian ini bertujuan untuk mendeskripsikan pengembangan produk instrument $e$-test sebagai inovasi penilaian berbasis online di Sekolah Dasar

Urgensi penggunaan instrumen e-test mampu mempermudah proses penilaian/evaluasi yang digunakan guru. Guru lebih mudah memantau aktivitas siswa karena guru tidak lagi disibukkan dengan ranah administrasi penilaian berbasis cetak. Hal ini sejalan dengan penelitian yang relevan yang dilakukan oleh Novrianti (2014) tentang pengembangan computer based testing (CBT) sebagai alternatif teknik penilaian hasil belajar. Hasil penelitiannya menunjukkan bahwa CBT layak digunakan sebagai media alternatif untuk memecahkan permasalahan pelaksanaan evaluasi pembelajaran. Perbedaan dengan peneliti sebelumnya yaitu penelitian sekarang tidak hanya mengukur tingkat hasil belajar saja, tetapi juga proses pembelajaran. Selain itu, produk yang dihasilkan saat ini terintegrasi dengan jaringan internet sehingga hasil nilai siswa lebih real time dan dapat dicermati oleh guru, siswa, dan orang tua.

\section{METODE}

Salah satu bentuk tes terdiri dari tes tertulis (paper and pencil test) yang dalam pelaksanaannya lebih mengutamakan pada penggunaan kertas dan pensil 
sebagai instrumen. Dalam pengerjaan tes tertulis lazimnya menggunakan tulisan tangan dan kertas ujian. Selanjutnya instrumen e-test yang dikembangkan yaitu berisi soal-soal atau instrumen dan dikemas dengan media komputer yang dapat dikerjakan oleh siswa secara mendiri baik secara online menggunakan jaringan internet maupun offline tanpa menggunakan jaringan internet.

Penelitian ini merupakan penelitian pengembangan yang metode penelitiannya menggunakan model pengembangan. Metode penelitian dan pengembangan ini mengadaptasi model O' Malley dan Pierce (1996) yang disesuaikan dengan kebutuhan penelitian yaitu lima tahapan diantaranya: 1) menentukan tujuan pengembangan, 2) menyusun spesifikasi produk, 3) melakukan pengembangan, 4) uji coba, dan 5) revisi. Penelitian ini dilaksanakan di SD Negeri Tlogomas 2 Malang, yang terletak di Jalan Raya Tlogomas, No. 1, Kecamatan Lowokwaru Kota Malang. Sumber data pada penelitian ini ialah validator, guru dan siswa

Uji coba dilakukan untuk mengumpulkan data yang digunakan sebagai dasar untuk menentukan tingkat kelayakan instrument E-Tes. Desain uji coba pengembangan intrumen E-Test ini diuji cobakan ke Validasi Ahli, praktisi pembelajaran, dan peserta didik. Subjek penelitian ini sesuai dengan desain uji coba pengembangan instrument E-Test diantaranya: a) validasi ahli subjek penelitiannya ialah ahli evaluasi pembelajaran dan ahli IT, b) praktisi pembelajaran ialah guru, dan c) peserta didik sekolah dasar.

Teknik pengumpulan data menggunakan angket validasi, yaitu validasi ahli materi dan ahli bahan ajar/test. Analisis data pada penelitian ini menggunakan analisis data kualitatif dan kuantitatif. Analisis data kuantitatif digunakan untuk mengolah data hasil review ahli evaluasi pembelajaran dan ahli IT, tanggapan guru, dan siswa. Analisis data kuantitatif digunakan untuk menyajikan data hasil angket sehingga tercapai kesimpulan penelitian.

\section{HASIL DAN PEMBAHASAN}

Pengembangan Instrumen e-test sebagai inovasi penilaian berbasis online di sekolah dasar melalui beberapa tahapan untuk menghasilkan produk yang layak untuk digunakan. Proses pengembangan Instrumen e-test melalui beberapa tahap menggunakan 
model pengembangan O' Malley dan Pierce (1996) yang disesuaikan dengan kebutuhan penelitian yaitu lima tahapan diantaranya: 1) menentukan tujuan pengembangan 2) menyusun spesifikasi produk, 3) melakukan pengembangan, 4) uji coba, dan 5) revisi.

Produk yang dihasilkan dalam pengembangan ini yaitu berupa instrumen e-tets onine yang dapat digunakan dalam alternatif melaksanakan penilaian pembelajaran menggunakan jaringan internet. Instrumen penialain yang dimaksud yaitu untuk memudahkan guru dan siswa dalam menerapkan penilaian berbasis online dalam pembelajaran tematik. Selanjutnya dengan dikembangkannya instrumen $e$-test berbasis online ini juga dapat membantu guru dalam melaksanakan penilaian pembelajaran tematik dengan pendekatan student approach.

Hasil analisis kebutuhan yang diperoleh dapat di SD Tlogomas 2 Malang telah menerapkan kurikulum 2013, proses pembelajaran telah menerapkan pembelajaran yang menggunakan media berbasis computer. Siswa sangat antusias ketika proses pembelajaran menggunakan media yang berhubungan dengan computer. Namun dalam melaksanakan penilaian hanya menggunakan perangkat instrumen paper based test. Hal ini menurut pemaparan guru belum ada inovasi terkait pengambilan penilaian kepada siswa. Ketika siswa merasa senang pembelajaran menggunakan media komputer tentu pada saat mengerjakan soal pada saat ulangan akan merasa antusias jika soal dapat dikemas dengan media yang berbasis komputer. Hal ini dapat meningkatkan motivasi belajar siswa.

Keadaan ini harus diperhatikan oleh guru untuk memfasilitasi siswa dalam meningkatkan kemampuan dan motivasi belajar siswa. Selain itu guru harus membuat alat penilaian yang inovatif yang berbasis media computer. Siswa akan merasa senang jika alat penilaiannya menggunakan media computer. Selain itu fasilitas yang dimiliki oleh sekolah harus dimanfaatkan dengan baik seperti tersedianya perangkat LCD dan jaringan internet sekolah. Fasilitas tersebut dapat dimanfaatkan oleh guru dalam pembuatan alat penilaian berbasis online. Alat penilaian yang berbasis media computer yang dikolaborasikan dengan jaringan internet akan menambah nilai guna dari alat penilaian tersebut. Maka dibutuhkan 
pengembangan alat penilaian yang berbasis online yang biasa disebut dengan instrument $e$-test.

\section{Spesifikasi Produk}

Menentukan spesifikasi produk harus mengetahui hasil analisis kebutuhan dan menetapkan produk yang akan dikembangkan, kemudian dapat menentukan spesifikasi produk yang dikembangkan yaitu rancangan instrument e-test. Rancangan ini adalah bagian dari prototype sederhana yang berisi gambaran pembuatan instrumen e-test. Proses membuat design e-test menggunakan aplikasi berbasis komputer. Aplikasi yang digunakan berupa open source yang sudah disediakan oleh google. Lebih lanjut aplikasi yang utama yaitu menggunakan jot form. Aplikasi ini digunakan untuk membuat e-test berbasis online dengan tampilan digital (elektronik). Adapun tampilan aplikasi yang dapat digunakan sebagai bahan e-test sebagai berikut.

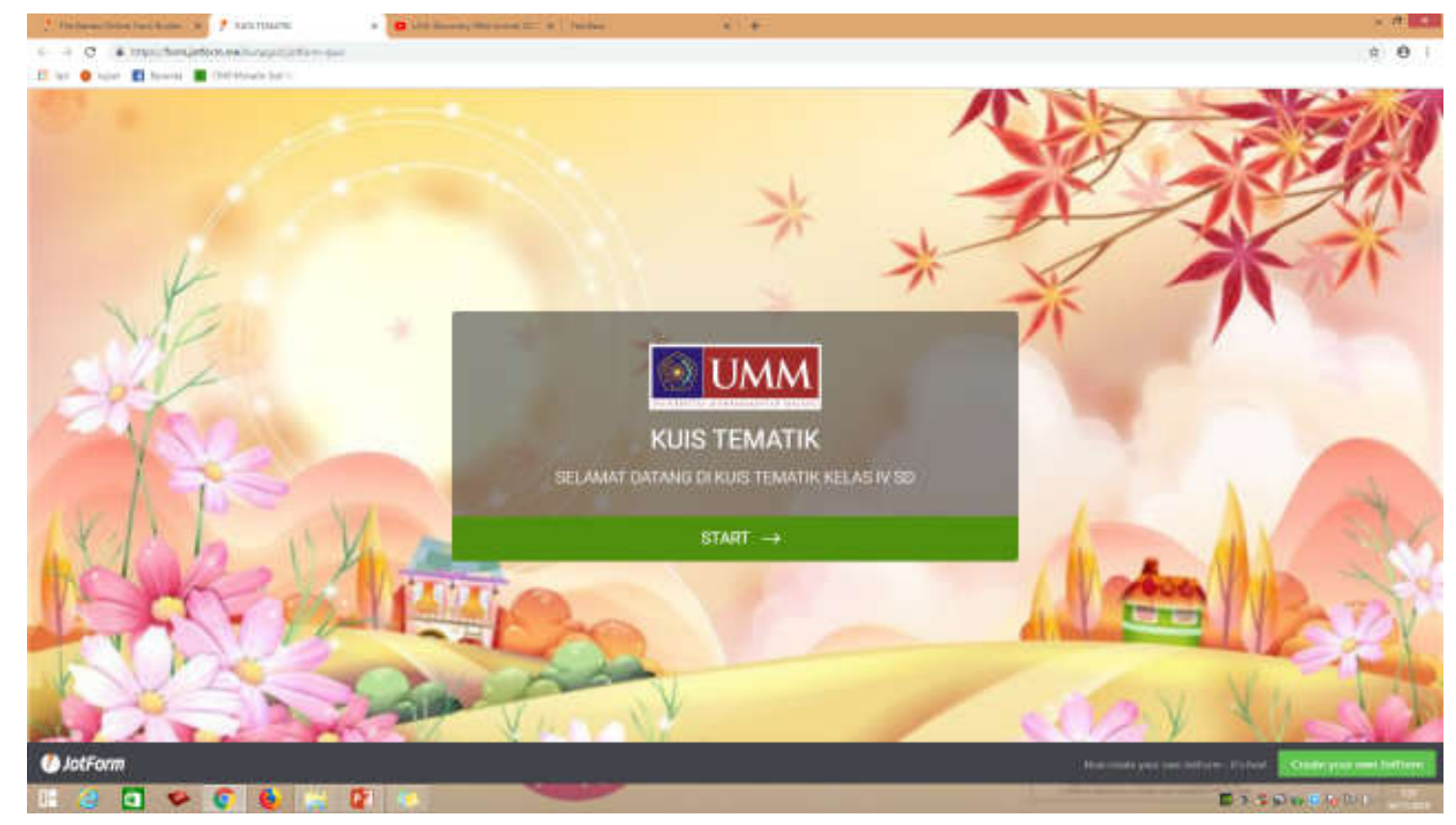

Gambar 1 Tampilan aplikasi Jot form berbasis open source (Dokumentasi Pribadi) 


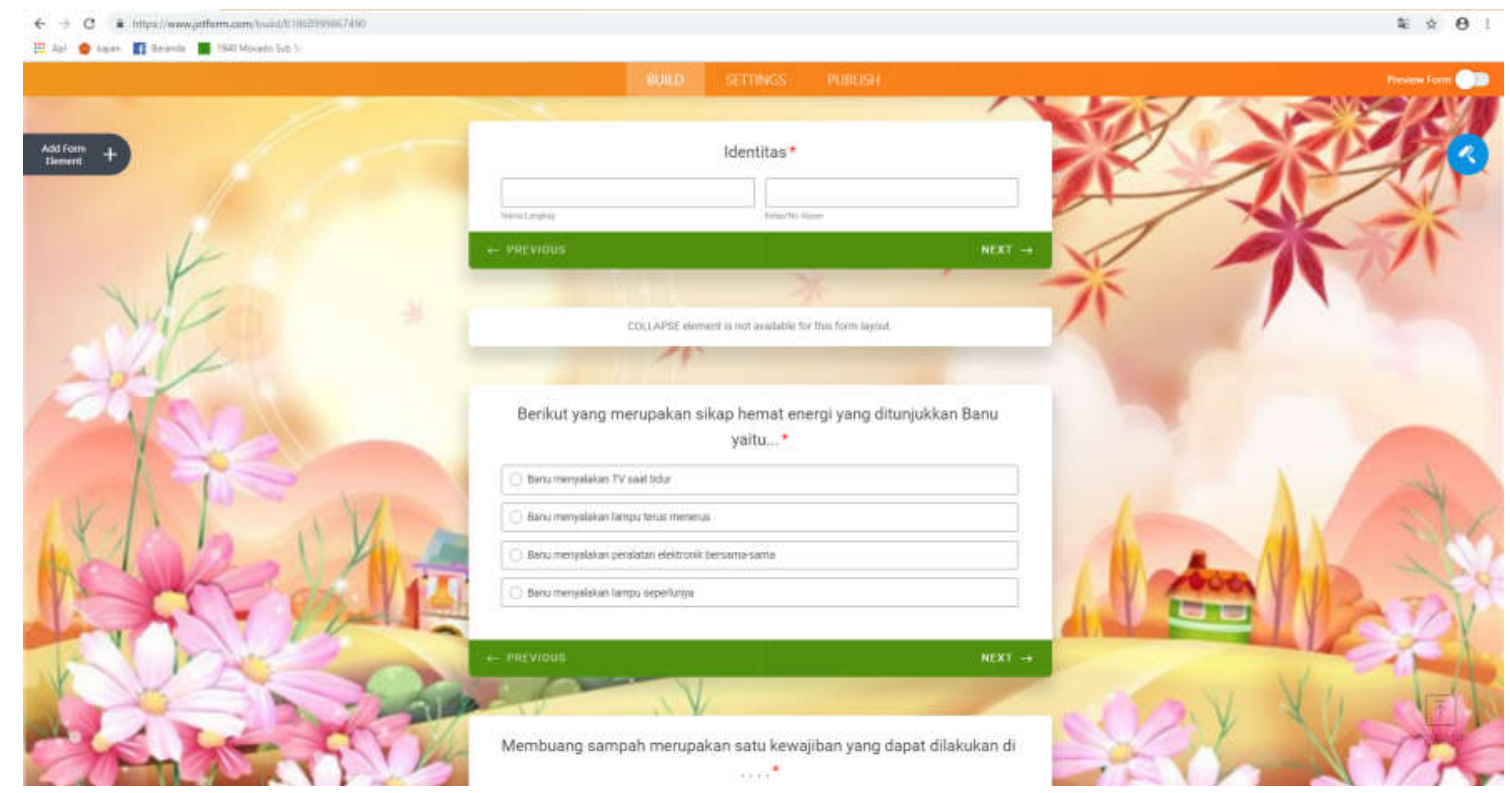

Gambar 2 Tampilan spesifikasi e-test berbasis online (Dokumentasi Pribadi)

\section{Pengembangan}

Setelah dibuat spesifikasi produk yang telah ditentukan kemudian proses pengembangan instrument e-test yang akan dikembangkan. Tahap proses pengembangan bahan ajar ini bertujuan untuk menghasilkan produk yang valid. Adapun proses pengembangan instrumen e-test sebagai berikut.

a. Menyusun spesifikasi Instrumen tes. Spesifikasi instrumen tes yang dimaksud yaitu jenis tes/penilaian yang dilakukan. Tes yang dilakukan untuk mengukur tingkat kognitif siswa. Bentuk tes berupa pilihan ganda dengan 4 pilihan jawaban.

b. Membuat butir soal dan jawaban. Setelah menyusun spesifikasi tes, selanjutnya menyusun butir soal dan jawaban sesuai dengan kebutuhan lapangan. Butir soal mengacu pada kurikulum yang berlaku.

c. Melakukan analisis butir soal dan jawaban. Pelaksanaan analisis butir soal dan jawaban dilakukan bertujuan agar butir soal dan jawaban menjadi valid/layak digunakan dalam penilaian. Proses analisis butir soal dan jawaban di lakukan bersama guru kelas IV SDn Tlogomas 2 Malang.

d. Pengembangan produk e-test dengan menggunakan aplikasi. Pada tahap ini tim peneliti melakukan pengembangan produk menggunakan aplikasi open source secara online. Aplikasi yang digunakan berupa plat form dari Jot form. Semua butir soal dan jawaban dimasukkan secara bertahap. Kemudian setiap 
soal berisi skor yang diperoleh kemudian pada bagian akhir soal terdapat total skor akumulasi yang diperoleh oleh pengguna tes. Secara eksplisit produk instrumen e-test yang sudah dihasilkan dapat dilihat sebagai berikut. Hasil pengembangan produk yang telah selesei kemudian dilakukan uji coba.

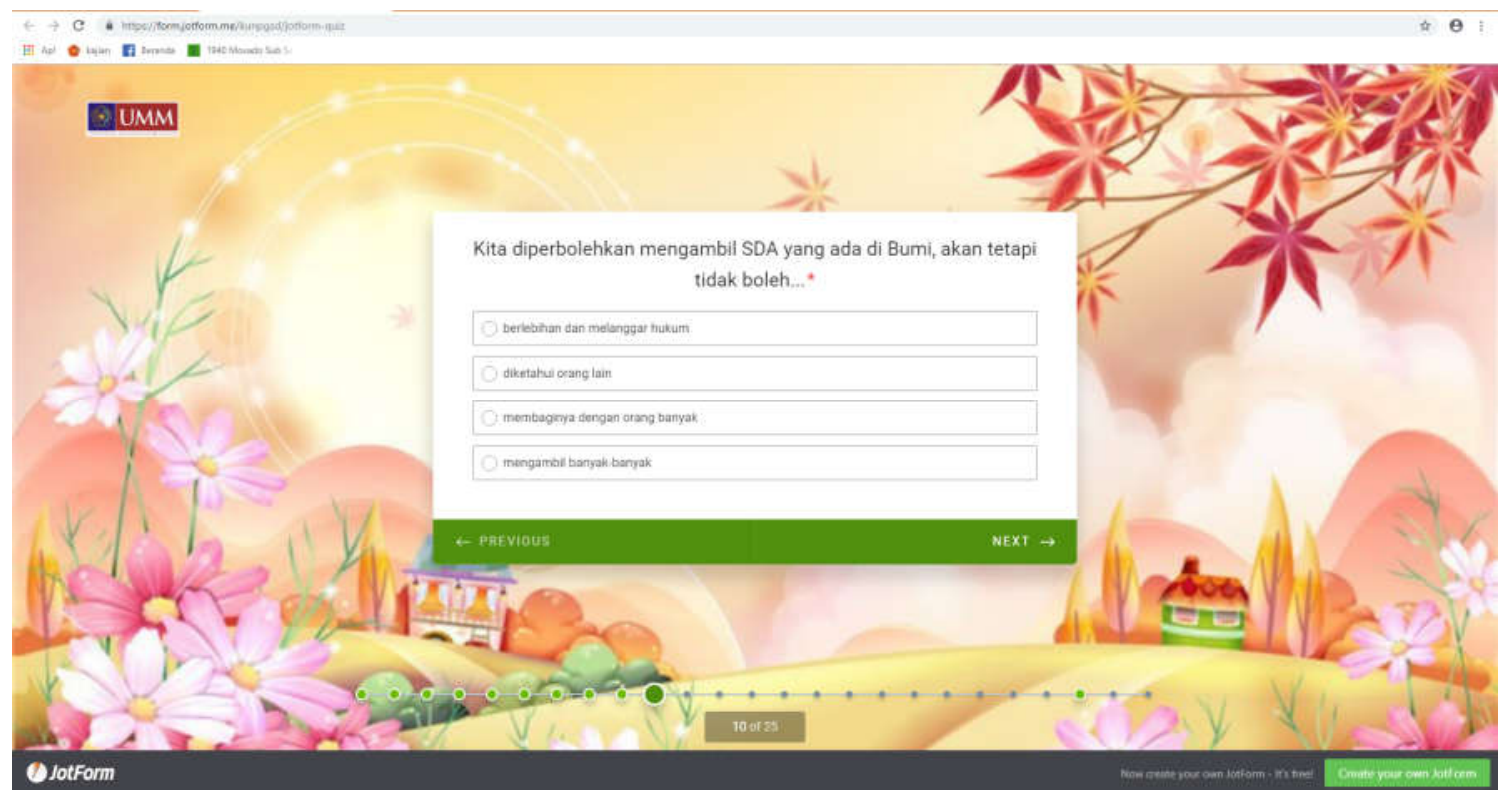

Gambar 3 Tampilan instrumen e-test (Dokumentasi Pribadi)

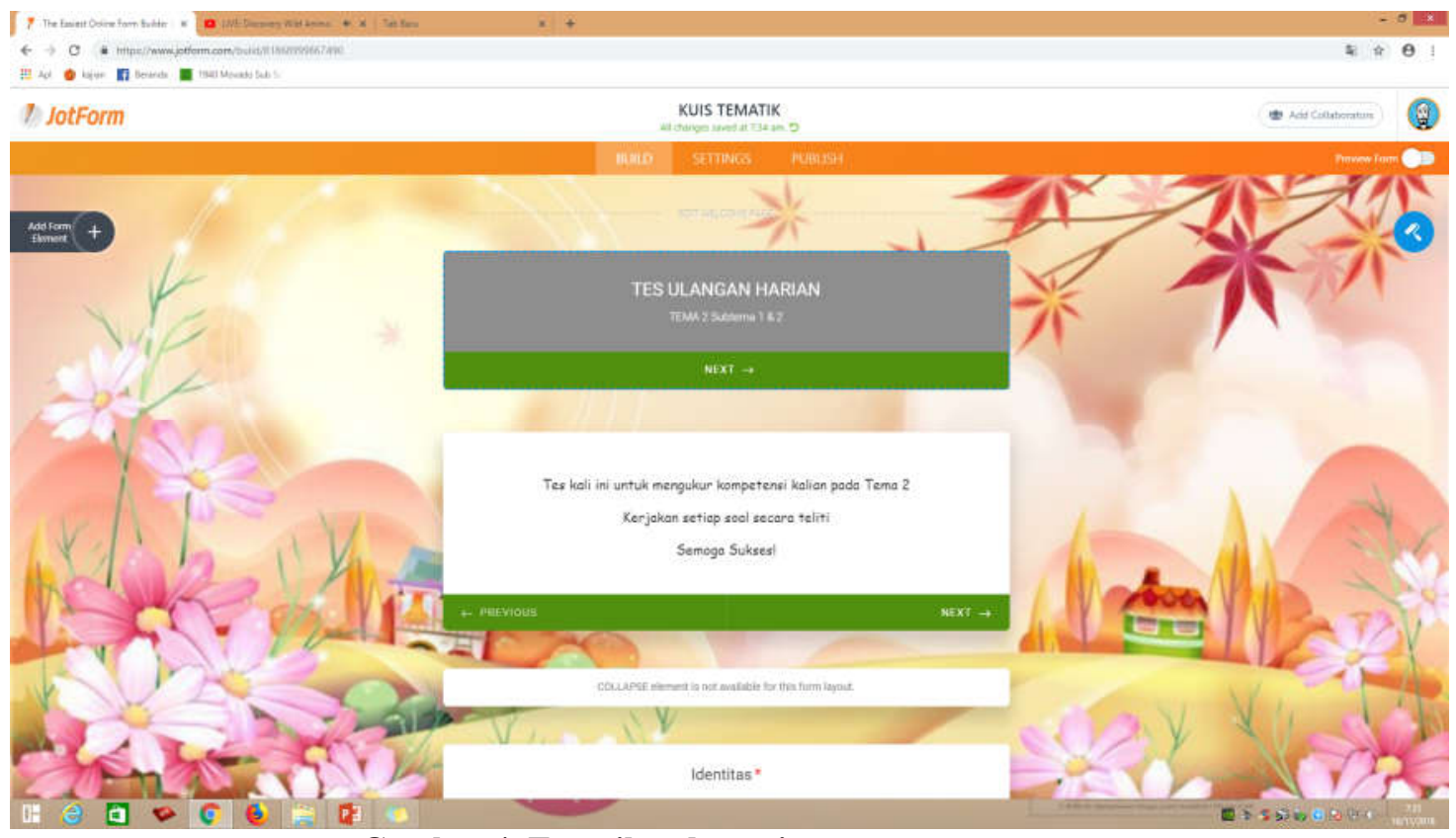

Gambar 4. Tampilan depan instrument e-test 


\section{Validasi Produk}

Produk yang selesei dikembangkan dilakukan proses validasi terlebih dahulu sebelum dilakukan uji coba lapangan. Produk pengembangan Instrumen $e$ test ini divalidasi oleh dua validator, yang pertama validator ahli evaluasi pembelajaran dan yang kedua validator ahli IT. Tahap ini dilakukan untuk mengetahui kevalidan produk yang dikembangkan untuk dapat di uji cobakan ke lapangan. Hasil validasi oleh validator evaluasi pembelajaran memperoleh persentase $84,6 \%$, persentase tersebut termasuk pada kriteria valid. Kemudian hasil validasi dari validator ahli IT memperoleh persentase $83,4 \%$ dengan kriteria valid. Hasil kedua validator menyatakan bahwa produk valid, hal ini dapat dikatakan bahwa produk siap untuk diujicobakan di lapangan.

\section{Uji Coba}

Tahapan ini merupakan implementasi dari langkah pengembangan model O’Malley yaitu uji coba lapangan. Uji coba produk ini dilakukan untuk mengukur tingkat respon siswa dalam menerapkan $e$-test pada pembelajaran tematik kelas IV SDN Tlogomas 2 Kota Malang. Data uji coba lapangan diperoleh dari guru sebagai praktisi pembelajaran dan siswa kelas IV SDN Tlogomas 2 Kota Malang yang dilakukan pada bulan Agustus 2018. Produk instrumen e-test yang sudah dikemas dalam content html atau internet yang sudah direvisi berdasarkan hasil uji oleh validator ahli, selanjutnya diuji cobakan dalam skala terbatas dan skala luas. Uji coba terbatas dilaksanakan di kelas IV SDN Tlogomas 2 Kota Malang yang berjumlah 10 siswa. Sedangkan ujicoba skala luas diuji cobakan pada seluruh siswa kelas IV SDN Tlogomas 2 Kota Malang. Hasil uji coba pada praktisi pembelajaran yaitu oleh guru mendapatkan hasil $84,1 \%$ dengan keterangan praktis untuk digunakan dalam pembelajaran, selain itu ada beberapa masukan yang diberikan untuk menyempurnakan produk. Kemudian uji coba pada skala terbatas kepada 10 siswa mendapatkan hasil 88,7\% dengan kriteria sangat praktis. Hasil uji coba skala luas yang dilakukan kepada seluruh siswa di kelas IV SDN Tlogomas 2 Kota Malang mendapatkan hasil 89,3\% sangat menarik untuk digunakan sebagai alat evaluasi dalam pembelajaran. Selain itu siswa terlihat sangat antusias 
dalam mengerjakan e-test dan fokus pada e-testnya masing-masing, sehingga bentuk kecurangan siswa hamper tidak terlihat.

\section{Revisi}

Berdasarkan hasil uji coba dan analisis data yang dikumpulkan, dilakukan revisi terhadap produk instrumen $e$-test untuk memperbaiki instrumen $e$-test yang dikembangkan sehingga dapat menghasilkan produk yang lebih baik. Berdasarkan analisis data yang dikumpulkan produk instrumen e-test pada pembelajaran tematik termasuk dalam kriteria valid atau boleh digunakan dengan revisi kecil, menarik, dan dapat digunakan sebagai inovasi pelaksanaan evaluasi berbasis online. Berikut ini adalah rincian revisi produk yang dilakukan sebagai berikut.

Hasil revisi produk merupakan bagian akhir dari proses pengembangan menggunakan model ADDIE. Proses evluasi dilakukan sebagai bentuk penyelesaian produk mulai dari tahap perancangan sampai dengan tahap ujicoba di kelas. Pada tahap revisi dilaksanakan untuk mengetahui hasil evaluasi secara kualitatif dan kuantitatif. Data kualitatif didapatkan dari angket validasi ahli, angket hasil uji coba ke pengguna (guru dan siswa). Data Kuantitatif didapatkan dari hasil skor uji coba yang diperoleh. Adapun gambaran tahap evaluasi yaitu sebagai berikut: 1) Evaluasi uji coba produk, 2) analisis data deskriptif, 3) revisi produk akhir, dan 4) hasil akhir produk.

Produk hasil penelitian dan pengembangan ini mengadaptasi model O' Malley dan Pierce (1996) yang disesuaikan dengan kebutuhan penelitian dengan lima tahapan meliputi: 1) menentukan tujuan pengembangan, 2) menyusun spesifikasi produk, 3) melakukan pengembangan, 4) uji coba, dan 5) revisi. Pada tahap menentukan tujuan pengembangan dilakukan dengan terlebih dahulu menentukan kebutuhan yang ada di lapangan. Berdasarkan hasil pengamatan awal dan wawancara kepada guru kelas IV didapatkan data terkait analisis kebutuhan dalam pembelajaran. Pada tahap menyusun spesifikasi produk yaitu berupa rancangan ini adalah bagian dari prototype sederhana yang berisi gambaran pembuatan instrumen $e$-test. 
Tabel 1 Revisi produk instumen $e$-test berdasarkan saran praktisi pembelajaran

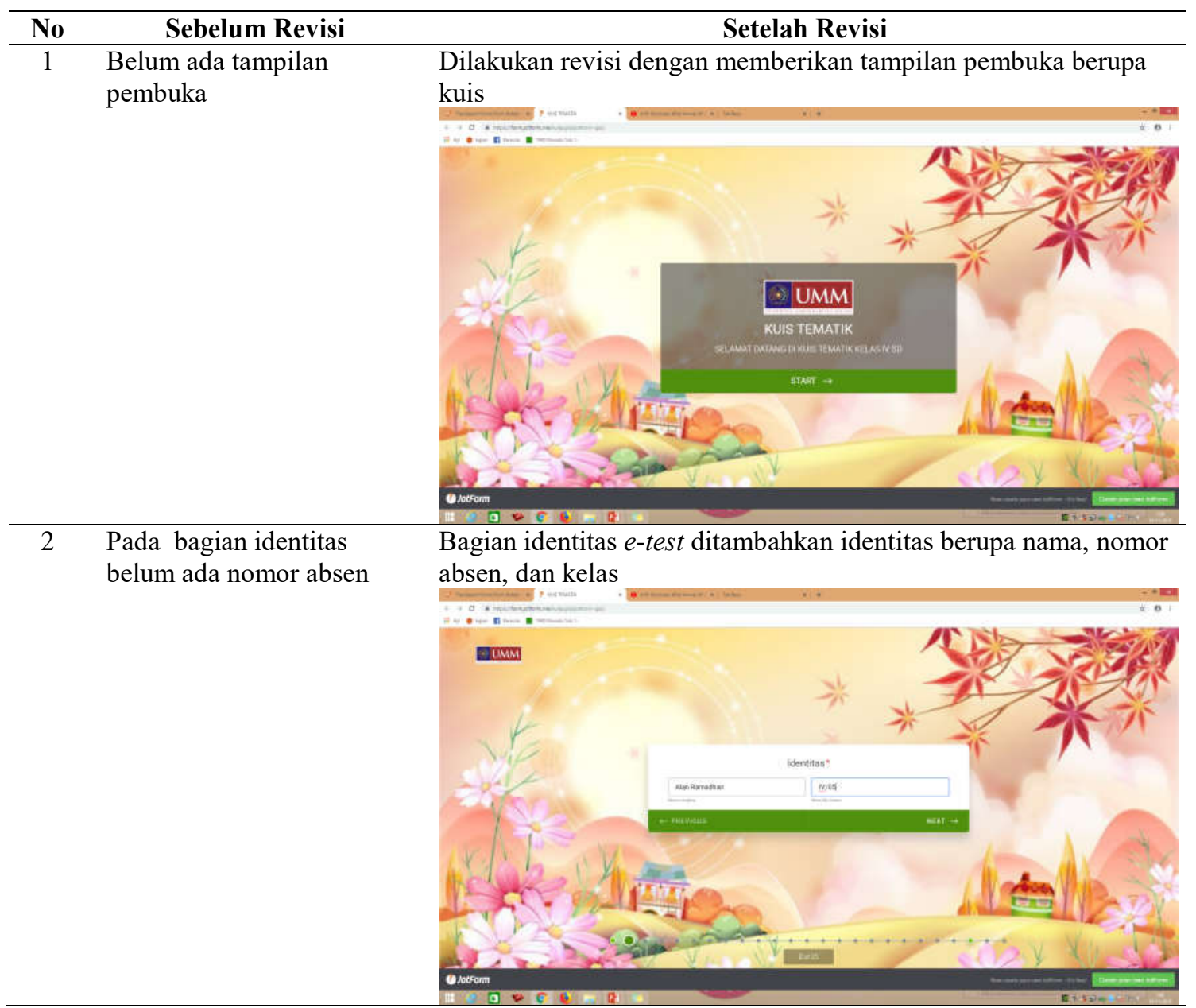

Sumber: angket respon guru

Jabaran tahapan selanjutnya pada setiap model pengembangan dapat dirinci sebagai berikut. Proses membuat design e-test menggunakan aplikasi berbasis komputer. Hal ini menjadikan siswa dapat mengerjakan tes secara mandiri dan siswa dapat berinteraksi secara interaktif dengan peritah yang diminta oleh aplikasi dengan bantuan computer. Hal ini selaras dengan penjelasan Percival dan Elington dalam (Ali 2005): mengatakan " dalam tutorial mode siswa berinteraksi langsung dengan computer yang telah diprogram untuk dimengerti isi programnya dan computer bereaksi terhadap respon-respon yang dilakukan oleh siswa".

Aplikasi yang digunakan berupa open source yang sudah disediakan oleh google. Sesuai dengan hasil riset Arnomo (2016) menghasilkan bahwa aplikasi open source berbasis web yang dapat di akses secara online melalui koneksi 
internet, dapat memudahkan untuk mempublikasikan dan menyebarluaskan karya-karya baru (bagi penulis atau peneliti) dengan mudah, cepat dan murah. Oleh karena itu perlunya pemanfaatkan aplikasi open source dapat diintegrasikan dalam pembelajaran di kelas.

Tahap ke tiga yaitu melakukan pengembangan dilakukan dengan prosedur menyusun spesifikasi instrumen tes, membuat butir soal dan jawaban, melakukan analisis butir soal dan jawaban, serta pengembangan produk e-test dengan menggunakan aplikasi. E-test yang dikembangkan diharapkan dapat menumbuhkan minat dan motivasi siswa dalam mengerjakan soal karena dengan e-test siswa dapat secara langsung melihat hasil yang didapatnya setelah mengerjakan soalnya. Hal ini sependapat dengan pendapatnya Jamil (2012) bahwa alat penilaian elektronik telah memfasilitasi dan mengurangi beban guru sehingga penilaian berbasis computer dapat digunakan untuk belajar lebih efektif dalam menguji berbagai keterampilan, pengetahuan dan pemahaman.

Produk yang telah dikembangkan menghasilkan hasil yang valid setelah divalidasi oleh validator, hasil tersebut mendapat kriteria valid dari hasil uji coba. Validitas e-test yang dikembangkan termasuk dalam kategori sangat layak yang berarti memiliki validitas yang tinggi, menurut Kunandar (2013) validitas yang tinggi mempunyai arti yaitu mampu mengungkapkan aspek hasil belajar tertentu secara tepat. Instrumen e-tes yang dikembangkan memiliki perbedaan tingkat kesulitan mudah, sedang, sulit dan redaksi soal tidak mengandung kalimat yang memiliki makna ganda, hasil belajar yang akan diperoleh akan mendapatkan data yang valid. Hal ini sependapat dengan Widoyoko (2010) instrument dikatakan valid apabila dapat mengukur apa yang hendak diukur sesuai dengan keadaan yang sebenarnya, dengan instrumen yang valid akan dapat menghasilkan data yang valid pula.

Selain itu soal yang ada pada e-test yang dikembangkan dalam penyajiannya dapat diacak, sehingga setiap siswa jika membuka aplikasi secara bersamaan akan menghadapi soal yang berbeda. Hal ini sejalan dengan apa yang dikatakan oleh (Nurhariyanti, 2011) mengatakan bahwa penyajian soal secara acak dapat digunakan sebagai salah satu alternative untuk menghindari kecurangan. Hal yang sama disampaikan oleh Rachma, dkk (2015) penyajian soal 
secara acak dapat dijadikan salah satu alternatif untuk menghindari kecurangan dalam pengerjaan soal.

Lebih lanjut melalui penggunaan e-test mampu meningkatkan kesan positif bagi siswa yang menggunakannya, karena tampilannya yang menarik membuat suasana dalam pengerjaan soal menjadi ceria. Sependapat dengan Clariana dan Wallace (2002) Ujian berbasis komputer memberikan dampak yang positif bagi siswa karena mengubah respons mereka disebabkan tampilan ujian yang lebih menarik. E-test yang dikembangkan dapat meminimalisir penggunaan kertas dan lebih efektif dalam penggunaan waktu. Selain itu dengan e-test mengurangi tindakan curang oleh siswa, karena siswa fokus pada soal yang ada di hadapannya. Mariskhana (2018) menyatakan dengan menghadirkan soal ujian berbasis komputer terdapat pengaruh signifikan terhadap daya kesiapan mental. Soal yang disajikan online mampu menstimulus respon mental positif siswa dalam menghadapi ujian.

Fakta tersebut sesuai dengan hasil penelitian yang dilakukan Meryansumayeka, (2018) menjelaskan bahwa dengan berkurangnya kecurangan yang ada, tiap siswa hanya fokus pada soal yang dihadapinya dan lebih menghemat waktu yang biasanya digunakan untuk bertanya atau saling berkomunikasi untuk mencari jawaban ke siswa lain dan dari segi ekonomi, penggunaan kertas pada uji tertulis bisa lebih diminimalisir. Bentuk instrument $e$ test sangat sesuai digunakan dalam mengurangi tingkat kecurangan yang dilakukan oleh siswa. Hal ini sesuai dengan apa yang disampaikan oleh Utomo (2015) kecurangan mahasiswa pada saat mengerjakan soal ujian diharapkan dapat diatasi dengan melaksanakan ujian online.

\section{SIMPULAN}

Penelitian ini menggunakan pengembangan model O'Malley dan Pierce dengan lima tahapan yaitu: menentukan tujuan pengembangan, menyusun spesifikasi produk, melakukan pengembangan, melakukan pengembangan, uji coba produk dan revisi. Bentuk produk berupa instrumen soal tes disertai jawaban yang memudahkan guru untuk melakukan penilaian online. Penelitian menghasilkan produk isntrumen berbasis online. Hasil uji coba bahwa produk 
valid dan hasil uji coba pengguna (guru dan siswa) bahwa instrumen berbasis online praktis digunakan sebagai alternatif penilaian berbasis online. Hasil uji coba skala luas yang dilakukan kepada seluruh siswa di kelas IV SDN Tlogomas 2 Kota Malang mendapatkan hasil 89,3\% sangat menarik untuk digunakan sebagai alat evaluasi dalam pembelajaran. Selain itu siswa terlihat sangat antusias dalam mengerjakan e-test dan fokus pada e-testnya masing-masing. Kepada peneliti selanjutnya diharapkan dapat mengembangkan instrument $e$-test dengan berbagai bentuk instrument yang bervarisi.

\section{DAFTAR PUSTAKA}

Ali, M, Dkk. 2005. Pengembangan Bahan Pembelajaran Berbantuan Komputer Untuk memfasilitasi Belajar Mandiri Dalam Mata Diklat Penerapan Konsep Dasar Listrik Dan Elektronika Di SMK. Laporan Penelitian Research Grant PHK A2 Jurusan Pendidikan Teknik Elektro FT UNY

Anderson, L.W., and Krathwohl, D.R. 2001. A Taxonomy of Learning, Teaching, and Assessing: A Revision of Bloom's Taxonomy of Educational Objectives. New York: Longman

Armono, Ilham. 2016. The Utilization of Open Source Applications for Scientifi c Repository College. Jurnal Ilmiah Ilmu-Ilmu Teknik dan Rekayasa, 3 (12), $70-76$

Barnett, J. E and Francis, A.L. 2012. Using Higher Order Thinking Questions to Foster Critical Thinking: A Classroom Study. Educational Psychology An International Journal of Experimental Educational Psychology ISSN14695820

Depdiknas. 2008. Peningkatan Mutu Pendidikan Di Sekolah Dasar. Jakarta.

Jamil, Suprihatiningrum. 2012. Strategi Pembelajaran Teori dan Aplikasinya. Jogjakarta: Ar-Russ Media

Kunandar. 2013. Penilaian Autentik (Penilaian Hasil Belajar Peserta Didik berdasarkan Kurikulum 2013). Jakarta: Raja Grafindo Persada.

Mariskhana, Katika. 2018. Pengaruh Tryout Dan Ujian Nasional Berbasis Komputer Terhadap Sikap Mental Siswa Pada Mts Al-Makmur Parungpanjang. Jurnal Ilmu-Ilmu Sosial, 3 (4), 222-234 
Meryansumayeka, dkk. 2018. Pengembangan Kuis Interaktif Berbasis E-Learning Dengan Menggunakan Aplikasi Wondershape Quiz Creator Pada Mata Kuliah Belajar Dan Pembelajaran Matematika . Jurnal Pendidikan Matematika, 12 (1), 29-42.

Mulyana, Deddy. 2007. Ilmu Komunikasi: Suatu Pengantar. Bandung: Remaja Rosdakarya

Nurhariyanti, S. 2011. Pengembangan Piranti Penyusun Soal Ujian Berbasis Web Untuk Mata Pelajaran Sekolah Menengah Pertama. [online]. Tersedia di: http://balitbang.kominfo.go.id/balitbang/bppki-yogyakarta/files/2012/06/02Pengembangan-Piranti-Penyusun-Soal-Ujian-Berbasis-Web-Untuk-MataPelajaran.pdf. [Diakses 23 November 2018]

Novrianti. 2014. Pengembangan ComputerBased Testing (CBT) sebagai Alternatif Teknik Penilaian Hasil Belajar. Jurnal Lentera Pendidikan.Vol. 17 no. 1 Juni 2014: 34-42

O’ Malley, J. Michael and Pierce, Lorraine Valdez.1994. Authentic Assessment for English Language Learners. USA: Longman

Rachma, Nurmaulidia Aulia, dkk. 2015. Pengembangan Test Elektronik E-Test Berbasis Komputer Pada Materi Bioteknologi Di SMA Negeri 1 Surabaya. Jurnal Berkala Ilmiah Biologi (Bioedu) 4 (3), 1018-1022

Clariana, Roy dan Patricia Wallace. 2002. Paper-Based versus Computer-Based Assesment: Key Factors Associated with the Test Effect. Jurnal Amerika.

Utomo. 2015. Pengembangan sistem ujian online soal pilihan ganda dengan menggunakan software Wondershare Quiz Creator. Jurnal Inovasi Pendidikan Fisika (JIPF), 4 (3), 1-6

Widoyoko.2010. Evaluasi Program Pembelajaran. Yogyakarta: Pustaka Belajar. 